\title{
AMAR
}

AMAR (Andalas Management Review)

Vol. 4, No. 2 (2020) 60-72

The Management Institute, Faculty of Economics, Universitas Andalas

ISSN (Print) 2476-9282 | ISSN (Online) 2548-155X

\section{The Effect of Perceived Ease of Use, Investment Knowledge, and Perceived Risk on Intentions to Purchase of Share of Generation Y}

\author{
Budi Setyantaa, Dian Citaningtyas Ari Kadib \\ a Program Studi Manajemen, Fakultas Ekonomi dan Bisnis Universitas Janabadra, \\ budi@janabadra.ac.id \\ ${ }^{b}$ Fakultas Ekonomi dan Bisnis Universitas PGRI Madiun
}

\begin{abstract}
Generation $Y$ investor growth is an appealing phenomenon for research. This study aims to examine the effect of perceived ease of use, investment knowledge, and risk perception on the purchase intention of generation $Y$ shares in Yogyakarta. This research used a convenience sampling technique through an online questionnaire for collecting 100 research data using. Hypothesis testing using multiple linear regression. The results of this study indicate that the research model meets the requirements of the goodness of fit. The research model can explain the data based on the theory used in this study. The results of this study indicate that remote sensing technology and transaction regulations that are simple and easy to understand and adequate investment knowledge affect the intention to buy of share in Generation Y. Comprehensive and accurate information provided by regulators and issuers provides a wealth of knowledge and information that helps Generation Y make the best investment decisions. Minimal transaction capital that is affordable results in less fear of generation $Y$ to invest. Generation $Y$ can manage risk well, so perceived risks is not a problem in investing.
\end{abstract}

Keyword: Perceived Ease of Use, Investment Knowledge, Perceived Risk, Intentions

\section{INTRODUCTION}

The number of investors in the Indonesian capital market in 2019 increased by $53.04 \%$ (Wareza, 2019), and group investors aged 18-25 years increased by $181.01 \%$ since 2016 (Jayani, 2019), which is greater than the growth in other age groups. The phenomenon of investor growth of generation $\mathrm{Y}$ is in that by a remote trading system application that makes it easy to make transactions. Besides, the minimum capital for share transactions is IDR 100,000 according to generation $Y$ financial capacity increasing generation $Y$ intentions to make transactions on the stock market, so that easy transaction from the office or home (Aldin, 2018). The ease of obtaining access to capital market information provides speed and accuracy in transactions because it helps in analyzing and making investment decisions, especially for tech-literate generation $\mathrm{Y}$.

Davis (1986) developed the concept of perceived ease of use. The concept of perceived ease of use is an individual's belief in understanding and using technology (Davis, 1986). 
The perceived ease of use is a minimum of effort because it is easy to learn, understand, simple, and easy to operate (Hartono, 2013). Perceptions of ease of use of a technology influence investor behavior. The intention for stock transactions increases when technology is perceived as easy to use, and vice versa.

The application of the concept of perceived ease of use has supported many kinds of research on various backgrounds and phenomena. Research by Hamid et al. (2016) indicates the perceived ease improves public schools in Malaysia to use e-government applications. Managers in Jordan have a good desire to use the internet if it is easy to operate (Akour, 2006). Simple operation increases the intention to use mobile banking (Raza et al., 2017), and ease of browsing e-commerce sites increases the intention to repurchase (Wilson, 2019). Previous research on various backgrounds and problems indicates that perceived ease of use is users feeling that the instructions for using technology are clear and easy to understand, less effort to operate, and technology by the user's wishes. These findings can be a driving force for companies trying to improve the ease of use of technology to increase the number of users and frequency of use. H1: perceived ease of using technology increases the intention to purchase shares in generation $Y$

Investment knowledge is all information, both facts or rumors that are considered in investment appraisal (Latha, 2016), as well as knowledge and ability to use investment concepts to reduce the potential risk of loss from investment (Taufiqoh et al., 2019). Investors should have knowledge about investment conditions, stock valuation, risk levels, and investment returns (Kusmawati, 2011). Knowledge influences the collection, management, and evaluation of information used in the decision-making process (Junaedi, 2007).

In the context of investing in the capital market, knowledge is the key to success, not luck and fortune. Without sufficient knowledge, investors face difficulties to initiate transactions. Investors need to understand the correct financial management in the future, so they must have the understanding to determine the type of investment that is most profitable in a certain period. Investment knowledge is information that has been processed that supports the commitment of investors to allocate resources to obtain future benefits by considering the risk and time.

Good knowledge helps investors choose the type of investment that is safe and profitable. Various investment offers will be on the table, and investors filter them and leave the most rational investment choices through the accurate information they have. Before investing, investors collect a variety of information to increase their knowledge and skills in 
conducting better analysis and decision making. Investors will increase or decrease their share influenced by the information quality of the capital market.

Previous research on the effect of investment knowledge on share purchase intention has been carried out, the results of this study indicate that sufficient knowledge is needed by investors to make profitable investment options (Pajar and Pustikaningsih, 2017; Wibowo and Purwohandoko, 2019; Amhalmad and Irianto, 2019). Investors need accurate, complete, and fast information to support decisions. H2: Sufficient knowledge increases the intention to pirchase shares in generation $\mathrm{Y}$.

Basically, all investments have a profit opportunity on the one hand and an opportunity for loss or risk on the other. The peril is attached to the investor so that the profit received is influenced by the risk that occurs. Risk is the chance of failure to achieve the expected return on investment. Risk is expressed as the possibility that part or all of the invested capital will not be returned. In investing, it contains an element of uncertainty or risk so that investors do not know with certainty the results of their investment. If investors expect high returns, they must be prepared to assume high risks as well.

Investors have different financial goals in the future, where to meet financial goals requires investment planning. The achievement of financial goals are adjusted to the period, namely short and long term, and the number of funds that can be set aside, where the expected results are related to the level of return. The expected returns will cohesive to the level of risk that must be borne. One must also consider their tolerance for risk (Saputra and Anastasia, 2013).

Risk is an essential factor to be considered in any investment decision making because the size of the hazard contained in an investment alternative will affect the expected income from the investment. The assessment of investors or potential investors on the risk of investing in shares will also affect the price of the shares concerned. This is because the risk is one of the elements in determining the discount rate to determine the value of shares (Setiowati, 1996). Investment decisions face uncertainty about results because there are potential risks.

Under normal conditions, the risk can be estimated more accurately. Stocks that can manage and estimates hazards properly will produce good financial performance and increase share prices, and vice versa. Improved financial performance supports an increase in share prices, and investors benefit from the growth in share prices, but if financial 
performance decreases, investors will lose because the stock price falls. This indicates that risk is a possible difference between the actual return and the return expected by investors. Investors set the level of risk expected in investing in determining the potential yield (Akbar, 2017).

Risk is an essential factor in making investment decisions because the level of risk in an investment alternative will affect the expected income. An investor's or potential investor's assessment of risk will also affect the price of the shares concerned because the risk is one of the elements in determining the discount rate for stock value (Setiowati, 1996). This opinion is supported by research conducted by Malik (2017) and Akbar (2017), which states that risk elements harm investment intentions. H3: The higher the perceived risk, the lower the purpose to purchase shares in generation $Y$

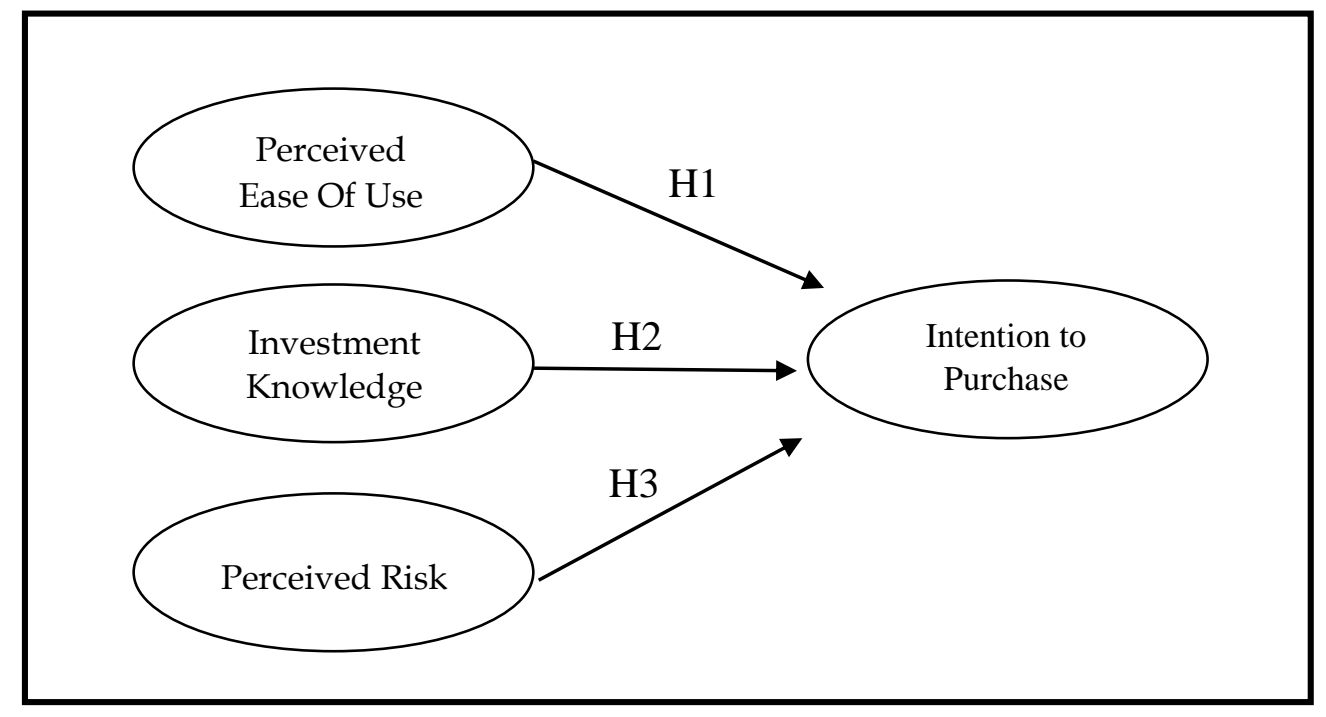

Figure 1. Research Model

\section{METHOD}

This research was conducted in the city of Yogyakarta and is categorized as an explanation study because it explains the causal relationship between the perceived ease of use, investment knowledge, and perceived risk to intention to purchase stock as a dependent variable. Data collection was carried out in September 2020, so this study is categorized as a cross-sectional study because data collection was carried out in a certain period. This study is only able to explain the phenomenon of the intention to buy shares $n$ that period.

This study consists of two variables, namely: Dependent Variable (intention to buy shares) and Independent Variable (perceived ease of use, knowledge, and perceived risk). 
The intention to buy shares is a desire to invest by purchase shares. Purchase intention according to a mental statement from the consumer that reflects the purchase plan for several products with a particular brand. Indicators of purchase intentions are as follows (Ferdinand, 2014): transactional intentions, referential intentions, preferential intentions, explorative intentions.

The population in this study were generation $\mathrm{Y}$ in Yogyakarta who intend on stock transactions with a total sample of 100. Data collection through surveys assisted by questionnaires using a Likert scale from $1=$ strongly disagree to $5=$ strongly agree. The technique used is to give questionnaires to sample online using google form through the convenience sampling technique

Davis (1986) is a pioneer of the concept of perceived ease of use. The perceived ease of use variable is the degree to which a person believes that technology can be easily understood and used. The ease indicators put forward by Davis (1986) are as follows: easy to learn, easy to operate, convenience according to user desires, it does not take a lot of effort to use.

The investment knowledge variable is the general knowledge investor has to make an investment. The variable measure used for investment knowledge is an understanding of investment conditions, information on stock valuation, the level of risk, and the return on investment (Kusmawati, 2011).

Risk is a vital factor in any investment decision making the potential risk in investment will affect the expected results. Investors' assessment of investment risk will affect the share price valuation. The risk indicators in this study are as follows (Akbar, 2017): Interest rate risk, inflation risk, business risk, financial risk, liquidity risk, currency exchange rate risk, country risk or political risk.

\section{RESULTS AND DISCUSSION}

\subsection{Validity and Reliability Test}

Table 1

Validity and Reliability Test

\begin{tabular}{lcc}
\hline \multicolumn{1}{c}{ Indicator } & $\mathbf{r}^{2}$ & $\begin{array}{c}\text { Cronbach's } \\
\text { Alpha }\end{array}$ \\
\hline Intention1 & 0,556 & \\
Intention2 & 0,514 & 0,870 \\
Intention3 & 0,522 & \\
Intention4 & 0,588 & \\
\hline
\end{tabular}




\begin{tabular}{lcc} 
PEOU1 & 0,645 & \\
PEOU2 & 0,688 & 0,877 \\
PEOU3 & 0,633 & \\
PEOU4 & 0,352 & \\
\hline Knowledge1 & 0,272 & \\
Knowledge2 & 0,234 & 0,761 \\
Knowledge3 & 0,502 & \\
Knowledge4 & 0,477 & \\
\hline Risk1 & 0,641 & \\
Risk2 & 0,706 & \\
Risk3 & 0,490 & 0,904 \\
Risk4 & 0,646 & \\
Risk5 & 0,770 & \\
Risk6 & 0,544 & \\
Risk7 & 0,643 & \\
Source: Statistical data processing $(2020)$
\end{tabular}

The validity test is used to determine whether a questionnaire is valid or not. A questionnaire is legitimate if the measured variable can be explained by the questions in the questionnaire (Ghozali, 2013). The validity test is to find out whether the measuring instrument used is proper what it should be measuring.

The number of samples in this study was 100, in a two-way test and a significance level of $5 \%$, then the $r$ table value at $r_{(0.05 ; 98)}$ was 0,1966 . The results of the validity test in table 1 show that all the calculated $r$ values are superior to the $r$ table values so that the data in this study are indicated as valid.

Reliability is a tool to measure the consistency of variables from time to time, a variable show to be reliable if Cronbach's Alpha is superior to 0,70 (Ghozali, 2013). The reliability test results in table 1 show that the Cronbach's Alpha statistic for all variables is above 0,7 . These results suggest that the questionnaire was answered consistently across studies and periods.

\subsection{Multiple Linear Regression Test}

Table 2. Multiple Linear Regression Test

\begin{tabular}{lccccc}
\hline & $\boldsymbol{\beta}$ & $\mathbf{t}$ & Sig & F & Adj. $\mathbf{R}^{\mathbf{2}}$ \\
\hline Constant & $-0,230$ & $-0,540$ & 0,590 & \multirow{2}{*}{41,451} & \multirow{2}{*}{0,551} \\
Perceived Ease Of Use & 0,573 & 3,895 & 0,000 & & \\
\cline { 5 - 6 }
\end{tabular}




\begin{tabular}{llll} 
Investment Knowledge & 0,396 & 3,537 & 0,001 \\
Perceived Risk & 0,077 & 0,583 & 0,561 \\
\hline
\end{tabular}

Variable Dependent: Intention to Purchase

Source: Statistical data processing (2020)

The Goodness of Fit test is a model feasibility test used to measure the accuracy of the sample regression function in estimating the actual value. The Goodness of Fit test is carried out by measuring the statistical value of F. The F statistical test basically shows whether all the independent in the model have a simultaneous influence on the dependent variable (Ghozali, 2013). The research model meets the requirements of the goodness of fit if the F statistical is more than 0.05 . The number of samples in this study was 100 and four variables. The $\mathrm{df}_{1}$ is $4-1=3$ and the $\mathrm{df}_{2}$ is $100-4=96$, so the $\mathrm{F}$ table is 2,47 . The independent variable has a simultaneous effect on the dependent variable if the F statistic is more than the F table. The F statistic is 41,451 , more than 2,70 indicate that the research model meets the goodness of fit requirements. Goodness-of-fit is a statistical model that describes how to fit the model developed with research data is (Olivares and Forero, 2010) and is used to test whether the developed model can explain the data according to the underlying theory (Hooper et al., 2008).

The contribution of perceived ease of use, investment knowledge, and perceived risk to the intention to buy shares in generation $\mathrm{Y}$ is $55,1 \%$ (see Adj. $\mathrm{R}^{2}$ in Table 2). This indicates that $55.1 \%$ of share purchase intentions in generation $Y$ can be explained by perceived ease of use, investment knowledge, and perceived risk, while the rest is explained by other variables not included in this study.

The results of this study show that the constant is $-0,230$, meaning that generation $Y$ has no intention of buying shares and feels loss if they do not find easy-to-use technology. Generation Y shies away from buying stocks if they do not have sufficient knowledge about investing. Millennials feel wrong if they are unable to manage potential risks in stock investing.

The constant confirms the goodness of fit that the perceived ease of use of technology, adequate investment knowledge, and the ability of generation $\mathrm{Y}$ to manage risk contribute significantly to share purchase intention.

Hypothesis testing uses the t-test to identify the effect of the independent variable on the dependent variable partially. The t-test shows the ability to explain one independent variable to the dependent variable, at a significance level of $5 \%$, so that the $t$ table is 1,9849 . 
The results of this study indicate that the perceived ease of use variable coefficient is 0,573 , the $t$ statistic is 3,223 more than 1,9849 , and the significance value is 0,000 less than 0,05 . The t-test results show that the perceived ease of use variable has a positive effect on the intention to buy shares in generation Y. Hypothesis 1 is supported.

The perceived ease of use is the individual's belief in the use of technology that is simple, easy to learn, understand, minimal effort in its operation (Hartono, 2013). Based on the above opinion, it can be concluded that perceived ease of use is the level where an individual believes that the perceived ease of use of a system is something that is not difficult to understand and the user does not require effort to operate it. Generation $Y$ investors will use technology for transactions if they have the confidence that the available technology is easy to use, and vice versa. The results of this study support the previous research of Dewi and Warmika (2016), which identified that the intention of customers to use mobile banking increases if the application is easy to operate, simple, and does not require time, effort, thought, and expense. The ease of use of a transaction technology can trigger consumers' desire to use the application in making purchases. The stock remote trading technology system is perceived to be easy to use. Generation $\mathrm{Y}$ is increasingly taking advantage of the ease of operating this technology for stock transactions. The stock remote trading technology is one of the stock trading services that easy to run in finding information related to the stock market, product information, and prices that make it easier for investors to find the desired product. Stock remote trading technology also makes it easy to operate in making transactions.

Investment knowledge is proven to have an effect on stock transaction intentions in generation $\mathrm{Y}$, the $\mathrm{t}$ statistic is 3.537 more than 1.9849 , and a significance value of 0.001 is less than 0.05 . These results support hypothesis 2 . This study supports previous research which indicates that sufficient investment knowledge increases the intention to buy shares (Pajar and Pustikaningsih, 2017; Wibowo and Purwohandoko, 2019; Amhalmad and Irianto, 2019).. This shows that an adequate investor understanding of the procedures, products, market character, opportunities, and risks of an investment increases the intention to buy shares in generation $\mathrm{Y}$.

Knowledge is the storage, integration, and organization of information obtained from the senses in memory. Therefore, science is the result of sensing a specific object, which is a very essential domain in shaping one's actions (overt behavior). Behavior that is based on knowledge will last more, and vice versa. 
Investment is the placement of someone's capital or funds to get high returns in the future. Knowledge has a critical role to play in guiding investors to get the best returns. Investors face problems in executing transactions without investment knowledge. Investors need to understand financial management to determine the choice of profitable investment instruments in the future. Investment is one way to organize and achieve a better financial life. A profitable investment is obtained by choosing the right instrument. Investment decisions must be supported by adequate knowledge and courage to make decisions quickly and accurately. Investors should have information quickly and accurately because business is very dynamic.

The field of investing is a big one, and there's almost a lot to learn about investing. The best and most successful investors are those who continue to learn and continue to hone and develop their skills in making money in the capital market. To learn knowledge about investing, it takes time. Willingness to learn about investing increases accurate information and practice in the stock market has the potential for the best financial returns. The success of an investment is determined by the investor's knowledge of the capital market. Without adequate knowledge, investors face difficulties in choosing investment alternatives in a variety of options that offer various advantages. Sufficient knowledge will filter all investment offers and leave the best choice of investment for investors.

The results of this study indicate that risk perception has no effect on the intention to buy shares in generation Y. It is confirmed that the $t$ statistic is 0.583 less than 1.9849 , and the significance is 0.561 more than 0.05 . Hypothesis 2 is not supported. The results of this study are not in line with the previous research of Malik (2017) and Akbar (2017). But the results of this study are in line with the finding of Raditya et al. (2014), Tandio and Widanaputra (2016), and Listyani et al. (2019), that sufficient knowledge of the stock market and a relatively small amount of investment are not the main concerns of Generation Y.

Perceived risk refers to the customer's perception of the risk associated with any purchase-related to an expensive, complex, and feature-rich product. This risk is felt to occur when consumers feel that a purchase decision can create potential harm or opportunity loss. Perceived risk is always subjective and varies from person to person. It may also differ from time to time. The main principle that all investors must understand is, nothing in this world is complete without risk. The risks and returns in investing are inseparable. Sufficient risk management knowledge is useful for mitigating risks. The investor's ability to manage risk confirms the ability to reduce risk consequences for future uncertainty. 
Investing is controversial because it can double the money we already have to pursue future dreams. On the other hand, investing also has frightening risks. In investing, knowledge and insight are needed to assess the credibility and sustainability of the investment products offered.

The stock market management policy reduces the minimum transaction value to IDR 100,000 , increasing the investment opportunities in Generation $Y$ because less money is already eligible to become investors. The minimum transaction requirement slightly reduces the perceived risks because IDR 100,000 does not make Generation Y pay more attention to capital that is at risk of being lost.

\section{CONCLUSION AND IMPLICATION}

This study aims to test a research model of intention to buy shares in generation $Y$ with a Yogyakarta background. This research model uses three independent variables, namely perceived ease of use, investment knowledge, and perceived risk. The results of statistical tests show that perceived ease of use and investment knowledge affect the intention to buy shares in generation $Y$. These show that the remote trading system operated by the stock market authority makes it easier for investors to make transactions and is a stimulus for generation $\mathrm{Y}$ to conduct stock transactions. Generation $\mathrm{Y}$ believes that the remote trading system used in stock transactions is easy to learn and operate, so there are no obstacles in using it. A technology used in an industry will have a positive impact in developing its business if it provides a perception of convenience and benefits its customers in terms of cost, effort, time, and easiness. Companies must promote technology that prospers customers because the simplicity felt by customers has an impact on increasing transactions, which are a source of profit and ensuring the continuity of company operations.

Investments face two possibilities, returns that increase the amount of money or losses that will impoverish investors. Investors can manage risk without being able to nullify it. In the context of investment, generation $Y$, which buys a small number of shares, does not consider investing to be an expense that grabs their attention. Generation $\mathrm{Y}$ is information and technology literate. They search for information and knowledge well before making investment decisions. Accurate information guides them to buy the most profitable stocks. Complete information and adequate literacy are assets to help make decisions that trust to be able to anticipate business environment uncertainties. Share issuers should build 
comprehensive and easy to understand information facilities that make it easier for investors to evaluate the quality of their shares.

Implications in further research need to add other variables, namely perceived benefits and perceived behavioral control, to increase the contribution of the independent variable to the dependent. This study shows that perceived ease of use, investment knowledge, and risk perception can explain $55.1 \%$ of purchase intention of generation $\mathrm{Y}$.

\section{REFERENCES}

Akbar. A., Hidayat. R., and Sulasmiyati. S. (2017), “Analisis kinerja investasi saham dengan metode sharpe model di beberapa bursa efek asean (studi pasar modal pada Fhilipina, Indonesia, Malaysia, Singapura dan Thailand tahun 2015- 2015)", Jurnal Administrasi Bisnis (JAB), Vol. 50, NO. $6: 1-8$

Akour, I., Alshare, K., and Miller, D. (2006), “An Exploratory Analysis of Culture, Perceived Ease of Use, Perceived Usefulness, and Internet Acceptance: The Case of Jordan", Journal of Internet Commerce (5)3 : 83-108.

Aldin, U. Ihya. (2018). “BEI Akan Pangkas Jumlah Minimal Transaksi Efek dari 100 Jadi 20 Saham". Available at :https:// katadata.co.id/safrezifitra/finansial/5e9a55e59b70b/beiakan-pangkas-jumlah-minimal-transaksi-efek-dari-100-jadi-20-saham. Retrivied 12 September 2020

Amhalmad. I., and Irianto, A. (2019), "pengaruh pengetahuan investasi dan motivasi investasi terhadap minat berinvestasi mahasiswa pendidikan Ekonomi Fakultas Ekonomi Universitas Negeri Padang", Jurnal EcoGen, Vol. 2, No. 4 : 734 - 746

Davis, D. Fred. (1989), "Perceived usefulness, perceived ease of use, and user acceptance of information technology", MIS Quarterly, 13 (3): 319-340, doi:10.2307/249008

Dewi, Ni Made and Warmika I Gde. (2016), "Peran Persepsi Kemudahan Pengguna, Persepsi Manfaat dan Persepsi Resiko Terhadap Niat Menggukan Mobile Commerce di Kota Denpasar". E-Jurnal Manajemen Unud, Vol. 5, No. 4 : 2606-2636

Ferdinand, Augusty. (2014), “Metode penelitian manajemen”, Semarang: BP Universitas Diponegoro. Semarang

Ghozali, Imam. (2013), “Aplikasi Analisis Multivariate dengan Program IBM SPSS 21 Update PLS Regresi", Semarang: Badan Penerbit Universitas Diponegoro. 
Hamid, A. A., Razak, F. Z. A., and Abu Bakar, A. (2016). “The Effects of Perceived Usefulness and Perceived Ease of Use on Continuance Intention to Use EGovernment". Procedia Economics and Finance 35 : 644-649

Hartono, Jogiyanto. (2013), “Metodologi Penelitian Bisnis Salah Kaprah dan PengalamanPengalaman", Edisi Keenam. Yogyakarta: BPFE

Hooper. D., Coughlan, J., and Mullen, R. (2008), “Structural equation modelling: guidelines for determining model fit". Electronic Journal of Business Research Methods, Vol, 6, No. $1: 53-60$

Jayani H, Dwi. (2019), “Tren Investor Milenial di Pasar Modal Terus Meningkat". https:/ / databoks.katadata.co.id/datapublish/2019/10/31/tren-investor-milenialselalu-meningkat. Retrivied 09 September 2020

Junaedi, Shellyana. (2007), "The roles of consumer knowledge and emotion toward ecological issue: an empirical study of green study consumer behavior", International Journal of Business, Vol. 9, No. $1: 81-99$

Kusmawati. (2011), “Pengaruh motivasi terhadap minat berinvestasi di pasar modal dengan pemahaman investasi dan usia", Jurnal Ekonomi Dan Informasi Akuntansi (JENIUS), Vol. 1, No. 2 : 103-117.

Latha, R. (2016), “Investors Behaviour Towards Investment Intention: A Study Of Investors Of Mutual Funds In Naapattinam District", International Journal of Innovative Research and Advanced Studies (IJIRAS), Vol. 3, Issue 9 : 73-78

Listyani. T., Rois. M., and Prihati. S. (2019), “Analisis pengaruh pengetahuan investasi, pelatihan pasar modal, modal investasi minimal dan persepsi risiko terhadap minat investasi mahasiswa di pasar modal (studi pada PT. Phintraco Sekuritas Branch Office Semarang), Jurnal Aktual Akuntansi Keuangan Bisnis Terapan, Vol. 2, No. $1: 49$ - 70

Malik. A. (2017), “Analisa faktor - faktor yang mempengaruhi minat masyarakat berinvestasi di pasar modal syariah melalui bursa galeri investasi UISI". Jurnal Ekonomi dan Bisnis Islam, Vol. 3, No. 1 : 61 - 84

Olivares, A. M., and Forero, G. (2010), “Goodness-of-fit testing”. International Encyclopedia of Education, Vol. 7: 190-196

Pajar, R., and Pustikaningsih, A. (2017), "Pengaruh motovasi investasi dan pengetahuan investasi terhadap minat investasi di pasar modal pada mahasiswa FE UNY", Profita Kajian Ilmu Akuntasi, Vol. 5, No. 1 : 1 - 15 
Raditya. D., Budiartha, K., and Suardikha, M. (2014), “Pengaruh modal investasi minimal di BNI sekuritas, return dan persepsi terhadap risiko pada minat investasi mahasiswa, dengan penghasilan sebagai variabel moderasi (Studi Kasus pada Mahasiswa Magister di Fakultas Ekonomi dan Bisnis Universitas Udayana)", E-Jurnal Ekonomi dan Bisnis Universitas Udayana, Vol. 3, No. $7: 377-390$

Raza, S.A., Umer, A. and Shah, N. (2017), “New determinants of ease of use and perceived usefulness for mobile banking adoption", International Journal of Electronic Customer Relationship Management, Vol. 11 No. 1 : 44-65.

Saputra. H., and Anastasia. N. (2013)," Jenis Investasi Berdasarkan Profil Risiko Herwono Indra Saputra dan Njo Anastasia, FINESTA, Vol. 1, No. 2 : 47-52

Setiowati. Ati. (1996), "Resiko investasi saham di pasar modal. jurnal hukum dan pembangunan", Vol. 26, No. $4: 313$ - 324

Tandio. T., and Widanaputra. A. (2016), "Pengaruh pelatihan pasar modal, return, persepsi risiko, gender, dan kemajuan teknologi pada minat investasi mahasiswa", E-Jurnal Akuntansi Universitas Udayana, Vol. 16, No. 3 : 2316 - 2341

Taufiqoh, E., Diana, N., and Junaidi. (2019), "Pengaruh norma subjektif, motivasi investasi, pengetahuan investasi, persepsi return dan literasi keuangan terhadap minat mahasiswa berinvestasi saham di pasar modal (studi empiris pada Mahasiswa Akuntansi FEB UNISMA dan UNIBRAW di Malang)", Jurnal Ilmiah Riset Akuntansi, Vo. 8 , No. $5: 9$ - 19

Wareza, Monica. (2019), “Hari Terakhir Bursa 2019, Investor Pasar Modal Capai 2,4 Juta”. https://www.cnbcindonesia.com/market/20191230142312-17-126472/hari-terakhirbursa-2019-investor-pasar-modal-capai-24-juta. Retrivied 09 September 2020

Wibowo, A., and Purwohandoko. (2019), "Pengaruh pengetahuan investasi, kebijakan modal minimal investasi, dan pelatihan pasar modal terhadap minat investasi (studi kasus mahasiswa FE Unesa yang terdaftar di galeri investasi FE Unesa)", Jurnal Ilmu Manajemen Vol. 7, No. $1: 192$ - 201

Wilson, Nicholas. (2019), “The impact of perceived usefulness and perceived ease-of-use toward repurchase intention in the indonesian e-commerce industry". Jurnal Manajemen Indonesia, Vol. 19 No. 3 : 241- 249. https://doi.org/10.25124/jmi.v19i3.2412 